\title{
Tst-1/Oct-6/SCIP regulates a unique step in peripheral myelination and is required for normal respiration
}

\author{
John R. Bermingham Jr., ${ }^{1,6}$ Steven S. Scherer, ${ }^{2}$ Shawn O'Connell, ${ }^{1}$ Edgardo Arroyo, ${ }^{2}$ \\ Kristin A. Kalla, ${ }^{1,5}$ Frank L. Powell, ${ }^{3}$ and Michael G. Rosenfeld ${ }^{4}$ \\ ${ }^{1}$ Department of Medicine, ${ }^{4}$ Howard Hughes Medical Institute, Department of Medicine, University of California, San Diego, \\ La Jolla, California 92093-0648 USA; ${ }^{2}$ Department of Neurology, University of Pennsylvania, Philadelphia, Pennsylvania \\ 19104-6077 USA; ${ }^{3}$ Department of Medicine, University of California, San Diego, La Jolla, California 92093-0623 USA
}

The terminal differentiation of myelinating glia involves complex interactions that culminate in the formation of myelin. The POU domain transcription factor Tst-1/Oct-6/SCIP is expressed transiently during myelination, and we report here that it has a critical role in this developmental process. Deletion of the Tst-1/Oct-6/SCIP gene produces a severe defect in peripheral myelination by arresting Schwann cell maturation before axonal wrapping. Unexpectedly, the activation of major myelin-specific genes appears to be unaffected by the Tst-1/Oct-6/SCIP mutation, demonstrating that multiple, independently regulated events are required for terminal differentiation of Schwann cells. In addition, aberrant differentiation and migration of specific neurons in Tst-1/Oct-6/SCIP mutant homozygotes is associated with a fatal breathing defect, providing a model for investigating the regulation of pulmonary homeostasis.

[Key Words: POU domain transcription factor; peripheral myelination; respiration; Tst-1; Oct-6; SCIP; nucleus of the lateral olfactory tract; phrenic nucleus; neuronal migration; Schwann cell]

Received April 16, 1996; accepted in revised form June 3, 1996.

Tst-1/Oct-6/SCIP is a member of the POU domain family of transcriptional regulators initially defined by the isolation of genes that encode the pituitary-specific transcription factor Pit-1/GHF-1 (Bodner et al. 1988; Ingraham et al. 1988), the octamer-binding proteins Oct-1 (Sturm et al. 1988) and Oct-2/OTF-2 (Clerc et al. 1988; Ko et al. 1988; Müller et al. 1988; Scheidereit et al. 1988), and by characterization of the Caenorhabditis elegans Unc-86 mutation (Finney et al. 1988). This family of proteins is characterized by its possession of a POU-specific DNA-binding domain, which is structurally similar to $\lambda$ repressor, tethered to a variant homeo domain (for review, see Herr et al. 1988; Verrijer and Van der Vliet 1993; Wegner et al. 1993a; Herr and Cleary 1995). The large number of POU domain transcription factors has been classified into six groups based on structural homologies (for review, see Verrijer and Van der Vliet 1993; Wegner et al. 1993a). Tst-1/Oct-6/SCIP is a member of the Class III POU domain proteins, which are expressed primarily in the developing and mature nervous system (He et al. 1989).

The Tst-1/Oct6/SCIP gene was characterized independently from rat testis and brain (He et al. 1989, 1991),

\footnotetext{
${ }^{5}$ Present address: Medical Center, Department of Pediatrics, Division of Human Genetics, University of California, Irvine, California 92668 USA. ${ }^{6}$ Corresponding author.
}

rat sciatic nerve (Monuki et al. 1989), F9 cells (Suzuki et al. 1990), mouse brain (Meijer et al. 1990), and epidermal keratinocytes (Faus et al. 1994). The Tst-1/Oct6/SCIP gene $(O t f-6)$ is located on mouse Chromosome 4 (Rohdewohld and Gruss 1992; Avraham et al. 1993), and is intronless; it appears to have evolved by retrotransposition (Kuhn et al. 1991). In the early mouse embryo, Tst-1/ Oct-6/SCIP expression undergoes two waves of induction and restriction, one in primitive ectoderm and one in primitive brain (Zwart et al. 1996). Later, it is expressed in multiple neuronal populations in the brain (He et al. 1989; Franz et al. 1994; Alvarez-Bolado et al. 1995). It is also expressed in embryonic stem (ES) cells (Meijer et al. 1990; Suzuki et al. 1990), testis (He et al. 1989), and epidermis (He et al. 1989; Faus et al. 1994). In the sciatic nerve, Tst-1/Oct6/SCIP is transiently expressed. Maximal expression occurs before the peak of myelin gene expression (Monuki et al. 1990; Scherer et al. 1994). In cultured Schwann cells, Tst-1/Oct-6/SCIP expression is up-regulated by axons (Scherer et al. 1994) and agents that raise the concentrations of intracellular cAMP (Monuki et al. 1989). In addition to its expression in myelinating Schwann cells, the Tst-1/Oct-6/SCIP gene is expressed at specific stages in the maturation of oligodendrocytes (Collarini et al. 1991, 1992).

The Tst-1/Oct-6/SCIP protein can function either as an activator of transcription or as a repressor. In tran- 
sient cotransfection assays, Tst-1/Oct-6/SCIP activates octamer-containing promotors (Suzuki et al. 1990; Meijer et al. 1992; Monuki et al. 1993b; Renner et al. 1994), the promotor for the acetylcholine receptor $\alpha 3$ subunit (Yang et al. 1994), and the JC virus early and late promotors (Wegner et al. 1993b; Renner et al. 1994), but represses the promoters of genes that encode the myelin structural protein $\mathrm{P}_{\mathrm{O}}$ (Monuki et al. 1990, 1993a,b; He et al. 1991), myelin basic protein (MBP; Monuki et al. 1990), nerve growth factor receptor (Monuki et al. 1990), and the keratin K5 and K14 promotors (Faus et al. 1994). An effector domain in the amino terminus (Meijer et al. 1992; Monuki et al. 1993a,b) is required for transactivation or repression and can act in a cell type-specific manner (Monuki et al. 1993b); maximal activation or repression, however, requires both the amino terminus and the POU domain. In addition to binding DNA, the POU domain acts also as a scaffold for protein-protein interactions (for review, see Herr and Cleary 1995); the POU domain of the Tst-1/Oct-6/SCIP protein interacts with the viral large $\mathrm{T} / \mathrm{small} \mathrm{t}$ antigens (Renner et al. 1994) and the non-histone chromatin proteins HMG-I/Y (Leger et al. 1995). These interactions suggest that Tst-1/Oct-6/ SCIP may function as part of cell type-specific complexes of proteins that can activate or repress genes.

Myelin, a structure required for rapid axonal conductance, is produced by oligodendrocytes in the central nervous system (CNS), and by Schwann cells in the peripheral nervous system (PNS). The Schwann cell lineage progresses through defined developmental stages from neural crest to produce myelinating and nonmyelinating Schwann cells (for review, see Jessen and Mirsky 1991, 1992; Eccleston 1992). Axons produce factors that promote the proliferation and maturation of precursor Schwann cells (Jessen et al. 1994; Dong et al. 1995; Gavrilovic et al. 1995). Axonal contact stimulates the differentiation of Schwann cells, perhaps in part through elevation of intracellular cAMP levels (Morgan et al. 1991; for review see Mezei 1993). After rapid proliferation and invasion of bundles of axons, myelinating Schwann cells cease cell division, then ensheathe and wrap large caliber axons (for review, see Webster 1993; Hildebrand et al. 1994), whereas nonmyelinating Schwann cells associate with small caliber axons, and retain many of the characteristics of immature Schwann cells. Based on evidence from transient cotransfection and transgenic mouse studies, it has been proposed that Tst-1/Oct-6/SCIP serves as a repressor of myelination in developing Schwann cells (Monuki et al. 1990, 1993a,b; Weinstein et al. 1995).

In this paper we report that disruption of the Tst-1/ Oct-6/SCIP gene results in defects of both neurons and peripheral myelinating glia. In the absence of Tst-1/Oct6/SCIP, mice exhibit a striking absence of peripheral myelin. Most myelinating Schwann cells appear to be arrested at the promyelinating stage, in which they have ensheathed a single axon in a 1:1 manner but have not yet formed a myelin sheath (Webster 1993). These arrested Schwann cells seem to express correctly several myelination-related transcripts, including mRNAs for $P_{0}$ and MBP. Central myelination by oligodendrocytes appears to proceed normally. The phenotype of Tst-1/Oct6/SCIP mutant mice redefines the critical role of this transcription factor in the maturation of myelinating Schwann cells and provides new insights into the complex regulatory mechanisms that control myelination. Furthermore, Tst-1/Oct-6/SCIP gene deletion results in a fatal defect in breathing that is distinct from its myelination phenotype and is associated with specific neuronal abnormalities.

\section{Results}

\section{Disruption of the Tst-1/Oct-6/SCIP gene}

To determine the role that Tst-1/Oct-6/SCIP has in the development of the cell types in which it is expressed, mice that lack the majority of Tst-1/Oct-6/SCIP-coding sequences were generated using (ES) cells. Targeted replacement of the entire amino terminus and POU domain with a functional $\beta$-galactosidase transcription unit (lacZ gene; Fig. la,b) resulted in a null mutation that allowed the fate of cells expressing the Tst-1/Oct6/SCIP promotor to be evaluated by X-gal staining. Heterozygous mice displayed no overt phenotype. Approximately one quarter of the pups born from heterozygous intercrosses were mutant (Fig. 1b), indicating their embryonic viability. Homozygous mutant mice lacked Tst1/Oct-6/SCIP protein (Fig. 1c), confirming that the gene was mutated, and the pattern of $\beta$-galactosidase expression in heterozygous animals accurately reflected that of the endogenous Tst-1/Oct-6/SCIP gene throughout development (Fig. 1d). Tst-1/Oct-6/SCIP (-/-) pups were usually cyanotic at birth and most died within $2 \mathrm{hr}$. However, rare $(-1-)$ mice appeared to breathe normally, and survived up to 22 days, although they were runted severely. These "outliers" were observed only among pups that possessed both 129/Sv and C57BL/6 genetic backgrounds (data not shown). No defects were noted in the skin, where Tst-1/Oct-6/SCIP is expressed strongly (He et al. 1991; Faus et al. 1994).

\section{Arrest of peripheral myelination in Tst-1/Oct-6/SCIP mutant mice}

To determine whether Tst-1/Oct-6/SCIP is essential for myelination in the CNS and PNS, we examined semithin sections of the spinal cord and sciatic nerve of Tst1/Oct-6/SCIP (-/-), (+/-; data not shown), and $1+1+1$ mice at post natal day 3 (P3). In the spinal cord, there were comparable numbers of myelinated axons in the ventral funiculus in mice of all three genotypes, indicating that Tst-1/Oct-6/SCIP is not essential for the development of mature oligodendrocytes, or the formation of their myelin sheaths (Fig. 2a,b). In contrast, there were dramatically fewer myelinated axons in the sciatic nerves of Tst-1/Oct-6/SCIP $(-/-)$ mice as compared with their $(+/-)$ and $(+/+)$ littermates (Fig. 2c,d). These results indicate that Tst-1/Oct-6/SCIP is required for the development of myelinating Schwann cells.

We examined P0 (day of birth) to P5 sciatic nerves by 
a
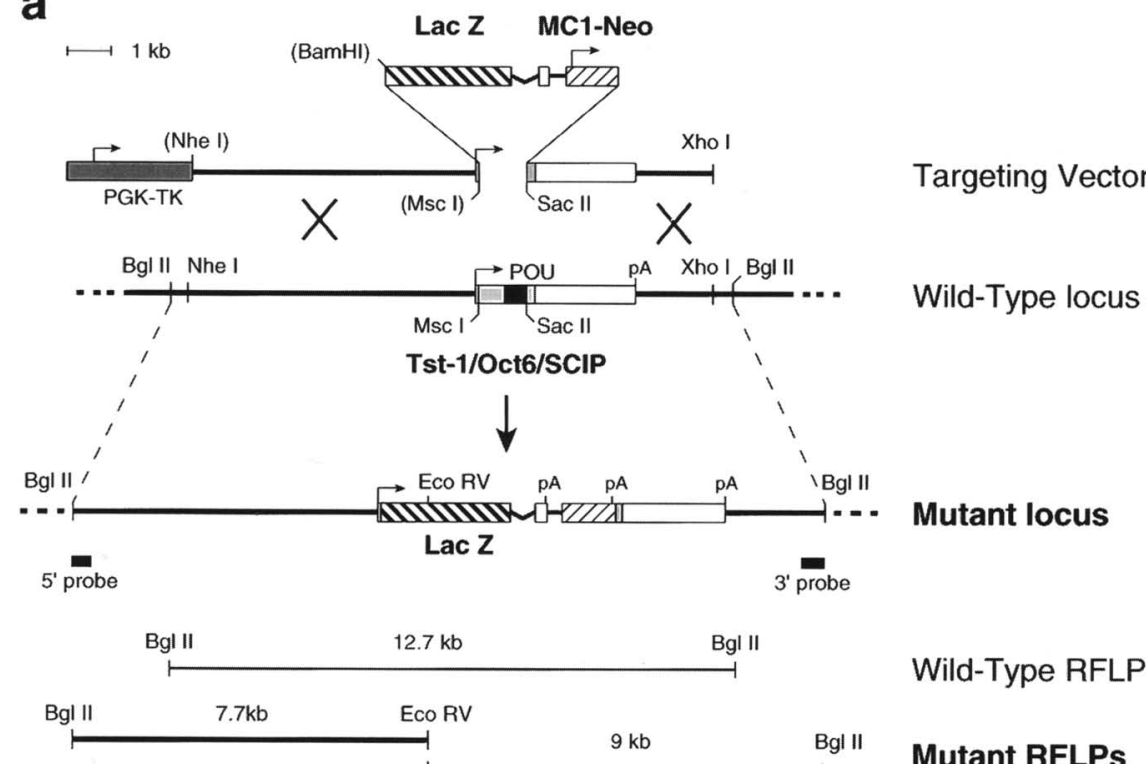

Wild-Type RFLP

Mutant RFLPs

b
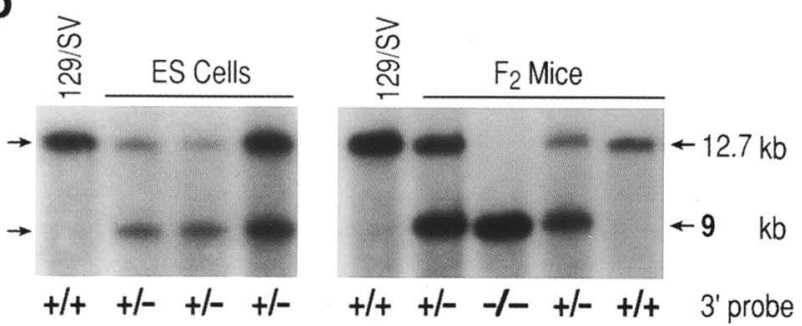

C

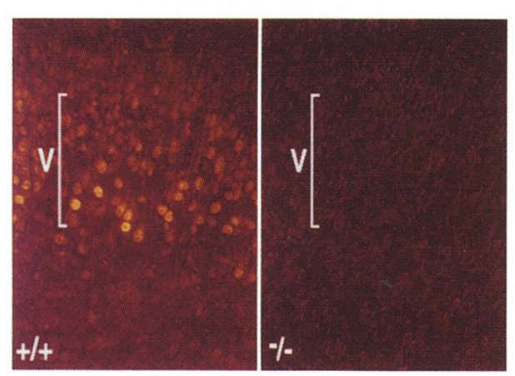

d

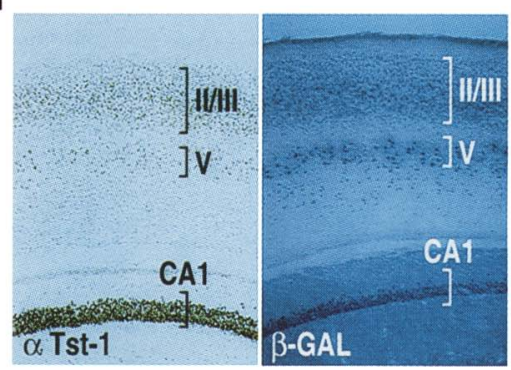

Figure 1. Disruption of the Tst-1/Oct-6/ SCIP gene. (a) The targeting vector is shown undergoing homologous recombination with the wild-type Tst-1/Oct-6/ SCIP locus, replacing the entire amino terminus and POU domain coding regions of Tst-1/Oct-6/SCIP with the lacZ gene and an MCl-neo expression cassette. Parentheses indicate restriction sites that were destroyed during construction of the targeting vector. Probes used to analyze homologous recombination are shown below the mutant locus, as are the wild-type and mutant RFLPs that are obtained when DNA from ES cells or mice is digested with BgIII and EcoRV. (b) $12.7-\mathrm{kb}$ wildtype and $9.0-\mathrm{kb}$ mutant RFLPs from three independent ES cell lines and from $F_{2}$ mice that result from hybridization to the $3^{\prime}$ probe. (c) Tst-1/Oct-6/SCIP protein is not detected in $(-1-)$ mice by an anti-Tst- $1 /$ Oct-6/SCIP antiserum. Layer $\mathrm{V}$ neurons are shown in transverse sections of cerebral cortex from P0 wild-type $(+1+)$ and mutant $(-/-)$ pups. Tst-1/Oct-6/SCIPimmunoreactive nuclei are absent from the $(-/-)$ PO brain. Scale bar, $63 \mathrm{~mm}$. (d) Anti-Tst-1/Oct-6/SCIP labeling of $1+1+1$ cortex, and $\beta$-galactosidase staining of $1+1$ $-\mid$ cortex, produce similar patterns of cortical layers II/III and V, and the CAl region of the hippocampus. Both sections are from 3-week-old mice; the antibody section is transverse, whereas the $\beta$-galactosidase section is sagittal. electron microscopy, to further evaluate the morphological defect in Tst-1/Oct-6/SCIP $(-1-)$ mice. At PO, Schwann cells in $(-1-1,(+1-)$, and $(+1+)$ mice appeared similar, having reached the promyelinating stage of their development; few, if any, myelin sheaths were seen. By P3 (Fig. 3a,b), the vast majority of axons in Tst$1 /$ Oct $-6 /$ SCIP $(-/-)$ mice were unmyelinated, as compared with their $(+1+)$ and $(+/-)$ littermates. In the $(-/-)$ mice, most myelinating Schwann cells failed to mature beyond the 1:1 ensheathment stage (Webster 1993 |, resulting in more Schwann cells in this configuration than in their $(+1+)$ and $(+1-)$ littermates. A few myelin sheaths that were found, however, that had a normal ultrastructure (Fig. 3c,d). Therefore, Tst-1/Oct$6 / S C I P$ is required for the maturation of myelinating
Schwann cells. Because Tst-1/Oct-6/SCIP expression correlates with Schwann cell proliferation in developing and transected nerves (Monuki et al. 1990), we counted the number of Schwann cell nuclei on low-magnification electron micrographs in $\mathrm{P} 3(-1-)$ and $(+1+)$ animals. The number of Schwann cells was comparable in both, indicating that no defect occurred either in the proliferation of Schwann cells or in their exit from the cell cycle. We examined the basal laminae in $(-1-)$ and $(1+1+1$ nerves, because Schwann cells require an intact basal lamina for axonal wrapping (for review, see Bunge et al. 1993 ) as demonstrated by the defective myelination in laminin $\alpha 2$-deficient $d y / d y$ mice (Stirling 1975; Weinberg et al. 1975; Xu et al. 1994). There were well-developed basal laminae surrounding every Schwann cell (ar- 


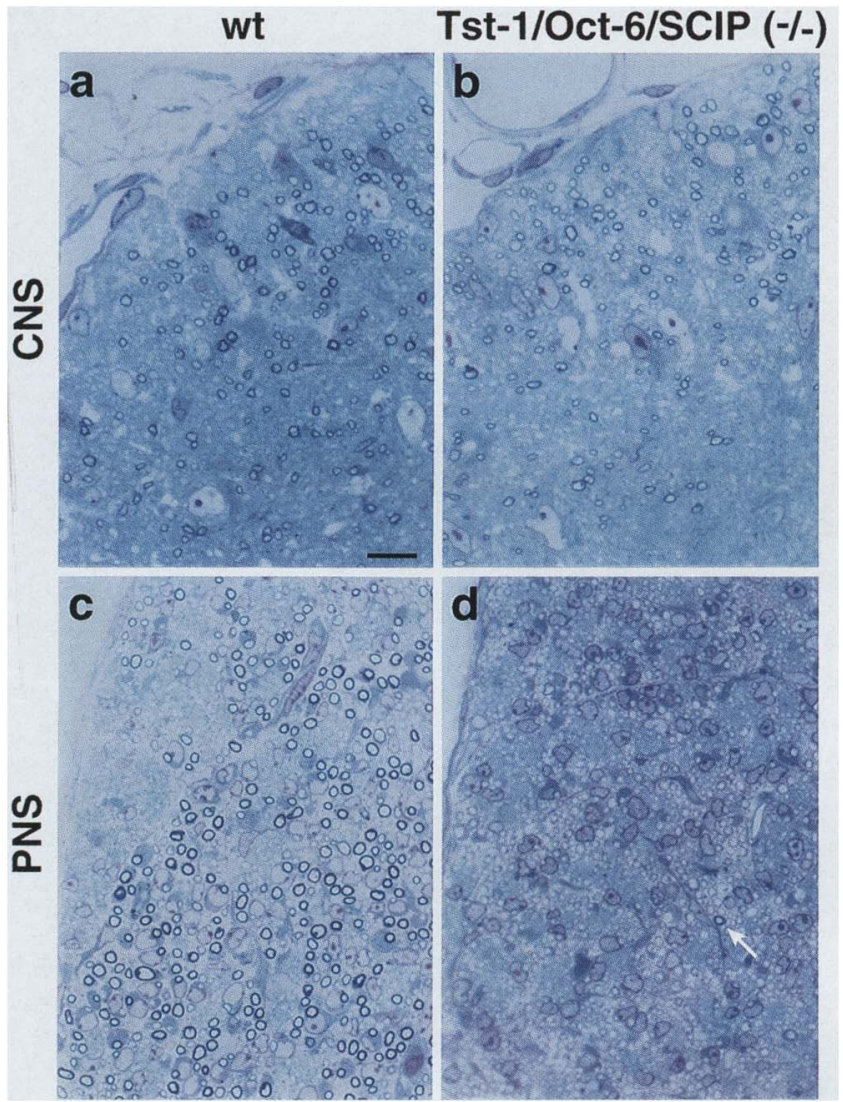

Figure 2. Myelination in the CNS and PNS of Tst-1/Oct-6/ SCIP $(-1-)$ mice. These photomicrographs of transverse, semithin sections of spinal cord $(a, b)$ and the sciatic nerve $(c, d)$ of a $\mathrm{P} 3(+1+)(a, c)$ and $(-1-\mid$ littermate $(b, d)$ demonstrate that myelination is impaired severely in the sciatic nerve, but not in the ventral funiculus in the $(-/-)$ animal. A single myelinated axon in $d$ is indicated by an arrow. Scale bar, $10 \mu \mathrm{m}$.

rows, Fig. $3 \mathrm{c}, \mathrm{d})$, therefore the failure of myelinating Schwann cells to develop in $|-|-\mid$ mice cannot be attributed to the absence of basal laminae.

\section{Myelination-specific gene expression in Tst-1/Oct-6/SCIP mutant mice}

To determine the effects of the Tst-1/Oct-6/SCIP mutation on the expression of specific Schwann cell proteins, antisera directed against these proteins were used for immunohistochemical analysis of $\mathrm{P} 4(+1-1,(-1-)$ and $1+1+$; data not shown) sciatic nerves. Normal laminin immunoreactivity around $(-1-\mid$ Schwann cells (Fig. 4a), provided further evidence that their basal laminae were unaffected by the mutation. $P_{0}$ protein was nearly absent in the mutant, except for occasional $\mathrm{P}_{0}$-positive myelin sheaths (Fig. $4 \mathrm{~b}$ ), which corroborated the observation of a few myelinated axons in $(-1-)$ nerves. MBP immunoreactivity was similar to that for $\mathrm{P}_{0}$ (data not shown). In contrast, both MAG and periaxin immunoreactivity were found around many axons in the mutant (Fig. 4c,d).
As both of these proteins have been shown to be localized to the adaxonal surface of myelinating Schwann cells in developing nerves (Gillespie et al. 1994), these data indicate that mutant Schwann cells not only ensheathe axons in the expected 1:1 manner, but also express MAG and periaxin, and correctly target them to their adaxonal surface. Therefore, even though these mutant Schwann cells fail to elaborate a myelin sheath, they possess many of the characteristics of initially myelinating Schwann cells.

We examined the mRNAs from several genes that are expressed during Schwann cell differentiation, to investigate further whether the expression of these genes is affected by the Tst-1/Oct-6/SCIP deletion. Tst-1/Oct-6/ SCIP had been thought previously to act as a repressor of $\mathrm{P}_{0}$ and MBP gene expression (Monuki et al. 1990; He et al. 1991; Weinstein et al. 1995). However, $\mathrm{P}_{0}$, MBP, and MAG expression signals were comparable in mutant and

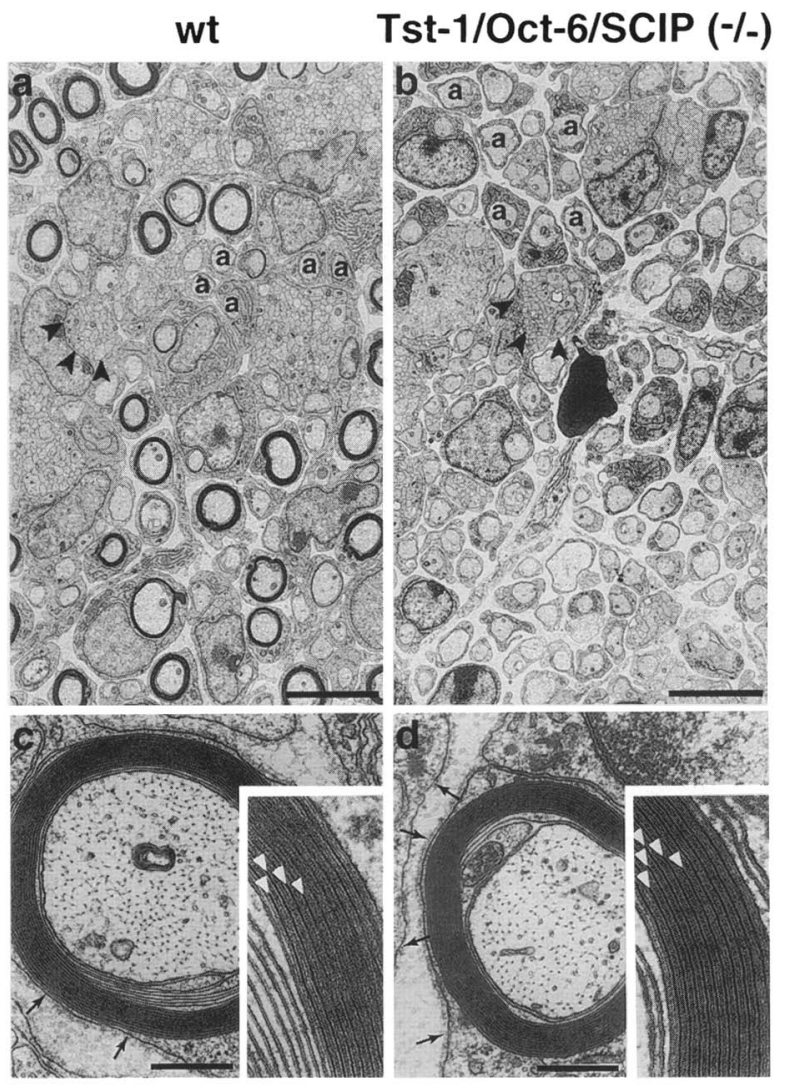

Figure 3. Myelination is deficient in Tst-1/Oct-6/SCIP mutant mice. (a) Wild-type. (a) Representative axons that have been ensheathed by Schwann cells in a 1:1 manner. Arrowheads mark bundles of unmyelinated axons. These electron micrographs demonstrate a lack of myelinated axons in Tst-1/Oct-6/ SCIP $(-1-)$ mice $(b)$ as compared with $(+1+1$ mice $(a)$. One of the few myelinated axons found in the $(-/-)$ mouse has a normal basal lamina (arrowheads in $d$ ) and myelin sheath (inset), with normal periodicity (15 nm) of the major dense lines (arrowheads); compare with the myelinated fiber in $c$, from a normal littermate. Scale bars, $5 \mu \mathrm{m}\langle a, b\rangle) 0.5 \mu \mathrm{m}(c, d)$. 

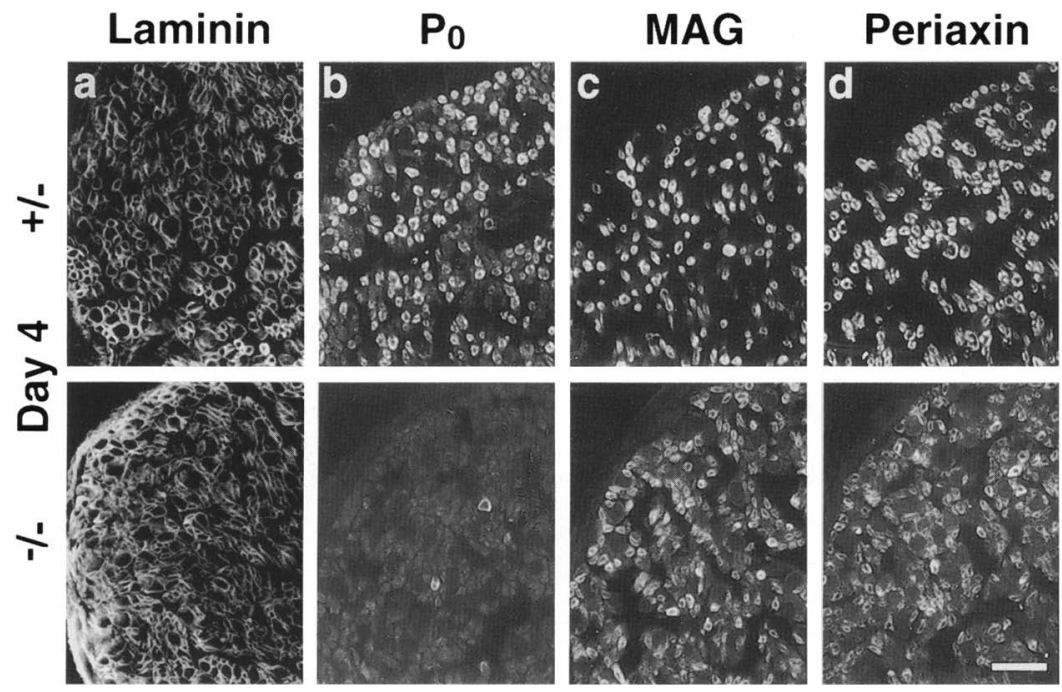

Figure 4. Myelin-specific protein expression in developing wild-type and mutant sciatic nerves. Adjacent sections from P4 $(+/-)$ and $(-1-)$ nerves were labeled for laminin $(a), \mathrm{P}_{0}(b), \mathrm{MAG}$ $(c)$, and periaxin (d) protein. There were many fewer $\mathrm{P}_{0}$-positive myelin sheaths in the $(-1-)$ nerve as compared with the $|+|-\mid$ nerve, whereas the number of MAG- and periaxin-immunoreactive Schwann cells were comparable. Although the apparent reduction in MAG and periaxin immunofluorescence in $(-/-)$ nerves may reflect the absence of Schmidt-Lanterman incisures and/or decreased expression of these proteins, both proteins are correctly targeted to the adaxonal membrane. Scale bar, $10 \mu \mathrm{m}$.

wild-type mice, both at P0 and at P4 (Fig. 5a-c), and comparable levels of $\mathrm{P}_{\mathrm{O}}$ mRNA were observed in $\mathrm{P} 10$ sciatic nerves from $(+/+)$ and $(-/-)$ mutant mice (Fig. $5 b)$. In addition, no differences in PMP-22 expression were observed (data not shown). Although in situ hybridization may not detect small differences in mRNA levels, these results strongly suggest that Tst-1/Oct-6/SCIP does not regulate directly the expression of these genes in vivo. The presence of normal levels of $P_{0}$ mRNA but reduced levels of $P_{0}$ protein in the $(-/-)$ sciatic nerves is consistent with the observation that Schwann cells shunt $\mathrm{P}_{0}$ protein to the lysosome under conditions that prevent myelination (Brunden and Poduslo 1987). p75 nerve growth factor receptor (NGFR) is down-regulated as Schwann cells differentiate (Morgan et al. 1991) and the normal pattern of p75 NGFR expression in mutant sciatic nerve (Fig. 5d) further indicates that mutant Schwann cells have initiated their differentiation toward a myelinating phenotype. Together, the immunohistochemistry and in situ hybridization results demonstrate that Tst-1/Oct-6/SCIP probably functions independently of the activation of the major myelin genes, indicating that multiple genetic pathways control myelination.

\section{Neuronal defects in Tst-1/Oct-6/SCIP (-/-) mice}

The respiratory failure in Tst-1/Oct-6/SCIP mutant mice may result from abnormal neuronal control of breathing and ventilatory drive, and/or failure of lung
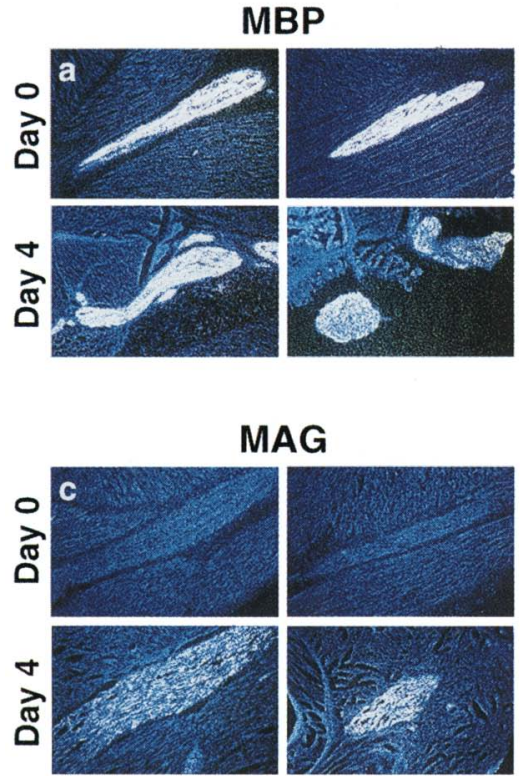

wt
$-1-$

$-$

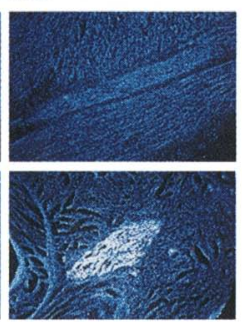

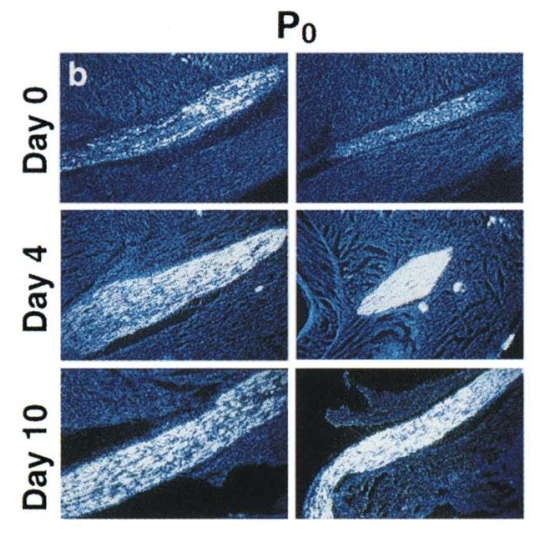

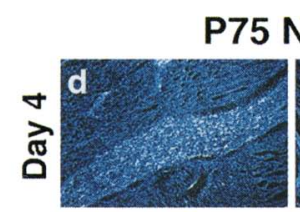

wt
$P_{0}$

Figure 5. In situ hybridization to sections from sciatic nerve of PO $(+/-)$ and $(-/-)$ littermates, and of $\mathrm{P} 4$ and $\mathrm{PlO}(+/+)$ and $(-/-)$ littermates, with antisense strand probes for $\mathrm{P}_{0}(a)$, MAG $(b), \operatorname{MBP}(c)$, and p75 NGFR $(d)$ demonstrates that the major myelin mRNAs are present at normal or near-normal levels in Tst$1 /$ Oct- $6 /$ SCIP $(-/-)$ mice, both at the onset of myelination $(\mathrm{P} 0)$, and after myelination has begun $(\mathrm{P} 4, \mathrm{P} 10)$. Examination of the contralateral sciatic nerves from the $\mathrm{P} 4$ mice confirmed that the mutant nerve was unmyelinated, in contrast to the control nerve (data not shown). No signal was observed on adjacent sections of PO and P4 sciatic nerve that were hybridized with $P_{0}$ and MAG sense strand probes (data not shown). 
gas exchange. This phenotype is unlikely to result from hypomyelination, because little or no myelination has occurred at birth and mutations in other genes that disrupt myelination do not result in these respiratory defects (Snipes and Suter 1995). Homozygous mutant pups exhibited variable degrees of disordering of the phrenic motoneurons and a possible decrease in their number (Fig. 6a,b), suggesting improper control of the diaphragm. In addition to its expression in phrenic motoneurons, Tst-1/Oct-6/SCIP also is expressed in many nuclei required for respiratory rhythm and airway caliber (Duffin et al. 1995; Feldman et al. 1995), including the nucleus tractus solitarius, the nucleus ambiguus, the glossopharyngeal nucleus, and the facial nucleus (Fig. $6 \mathrm{c}, \mathrm{d}$ ). Although most mutant pups died too quickly to permit a meaningful respiratory analysis, four mutant pups that survived for several hours displayed a significant reduction in breathing frequency when compared with 10 homozygous wild-type littermates $169 \pm 7$ SEM vs. $107 \pm 8$ SEM; unpaired $t$-test, $P=0.013$; Fig. 6e). Heterozygous pups displayed an intermediate frequency $\{91+9$ SEM, $n=17$ ). Breathing was more irregular in mutant pups, and tended to occur in periodic bouts with long periods of apnea between bouts. The differences between the surviving homozygous mutant pups and homozygous wild-type pups in tidal volume per gram of body weight, or in inspiratory volume per gram of body weight, were not significant. There were no obvious differences between the mutants studied and their wild-type littermates in the magnitude of the ventilatory response to acute $(30 \mathrm{sec})$ or sustained $(3 \mathrm{~min})$ hypoxia, the ventilatory decline during sustained hypoxia or on restoration of normoxia after sustained hypoxia, or the ventilatory response to hypercapnia (data not shown). Although no gross anatomical differences were observed in lungs from mutant and wild-type pups, the results of histologial examination of lung sections from several moribund neonatal mutant pups (data not shown) suggests that improper lung inflation may cause the respiratory failure of the mutant pups that die immediately after birth. Tst1/Oct-6/SCIP expression has not been observed in lung at el3 d.p.c. (days post-coitum) or el6 d.p.c. in rat (He et al. 1989) or at birth in mouse (data not shown), suggesting that the effect of the Tst-1/Oct-6/SCIP mutation in lung is non-cell autonomous.

Although most brain regions in homozygous Tst-1/ Oct-6/SCIP $(-1-)$ mice were structurally indistinguishable from those of heterozygous mice, staining whole brains for $\beta$-galactosidase revealed a defect in the nucleus of the lateral olfactory tract (NLOT; Fig. $6 \mathrm{f}-\mathrm{j}$ ). At E18.5, NLOT in heterozygotes is near the ventral surface of the brain, whereas in mutants, putative NLOT cells are located in the interior of the brain (Fig. 6f). In P0 heterozygous brains, NLOT can be observed in its normal position, posterior to the lateral cerebral sulcus that separates the lateral olfactory tract from the olfactory tubercle. In PO $(-1-)$ brains, NLOT is consistently missing from its normal location, and is often replaced by a new, dispersed patch of $\beta$-galactosidase-positive cells appearing medial and anterior to the lateral cerebral sulcus (Fig. 6g). Additional patches of abnormal cells are occasionally seen. At P4, the displaced $(-/-)$ NLOT is smaller than the $1+1-1$ NLOT, or is absent altogether. Occasional abnormal axon tracts can be observed emanating from the vicinity of the $(-/-)$ NLOT (Fig. 6h). By P10, no staining of NLOT cells can be observed in $(-1-)$ brains (Fig. 6i). The locations in P0 and P4 brains of normal and putative displaced NLOT cells are diagramed in Figure 6j. The most likely interpretation of these data is that during development, neurons of NLOT migrate to their final position, and that this migratory event, and the subsequent survival of these neurons, requires expression of Tst-1/Oct-6/SCIP.

\section{Discussion}

Role of Tst-1/Oct-6/SCIP in Schwann cell differentiation

The phenotype of Tst-1/Oct-6/SCIP mutant mice reveals that this POU domain factor exerts a critical regulatory function in peripheral myelination. The maturation of myelinating Schwann cells and the pattern of Tst-1/Oct-6/SCIP expression during myelination are summarized in Figure 7. In Schwann cells, Tst-1/Oct-6/ SCIP expression is transient, probably activated by axonally induced increases in levels of intracellular cAMP (Monuki et al. 1989; Scherer et al. 1994); Tst-1/Oct-6/ SCIP expression declines as myelin sheath formation commences (E. Arroyo, J. Bermingham Jr., M.G. Rosenfeld, and S. Scherer, unpubl.). Deletion of Tst-1/Oct-6/ SCIP does not affect the number of Schwann cells, indicating that no proliferative defect has occurred. Tst-1/ Oct-6/SCIP mutant Schwann cells possess a unique phenotype that exhibits many of the characteristics of myelinating Schwann cells. They form 1:1 associations with axons, produce a normal basal lamina, and properly localize MAG and periaxin to the adaxonal membrane. Although the Tst-1/Oct-6/SCIP mutation does not appear to affect the expression of myelin structural genes, $\mathrm{P}_{\mathrm{O}}$ and MBP protein expression is decreased, and axonal wrapping is disrupted. Wrapping is not critically dependent on the major myelin proteins because Schwann cells from mice that lack $P_{0}$ (Giese et al. 1992), MAG (Montag et al. 1994), PMP22 (Adlkofer et al. 1995), or both $\mathrm{P}_{0}$ and MBP (Martini et al. 1995) are able to progress beyond the ensheathment stage. Therefore, the targets of Tst-1/Oct-6/SCIP regulation are critical regulators of axonal wrapping.

Deletion of Tst-1/Oct-6/SCIP in mice has resolved conflicting views of its potential role in the activation or repression of myelin genes. Previously, Tst-1/Oct-6/ SCIP had been postulated to function in myelination by repressing $\mathrm{P}_{0}$ and $\mathrm{MBP}$ gene expression, based on its repression of the $\mathrm{P}_{0}$ and MBP promotors in transient cotransfection studies (Monuki et al. 1989 1993a,b), and on the actions of $\triangle S C I P$, a putative dominant-negative truncated form of Tst-1/Oct-6/SCIP, which retains the POU domain and carboxyl terminus (Weinstein et al. 1995). $\triangle S C I P$ precociously activates myelination when ex- 

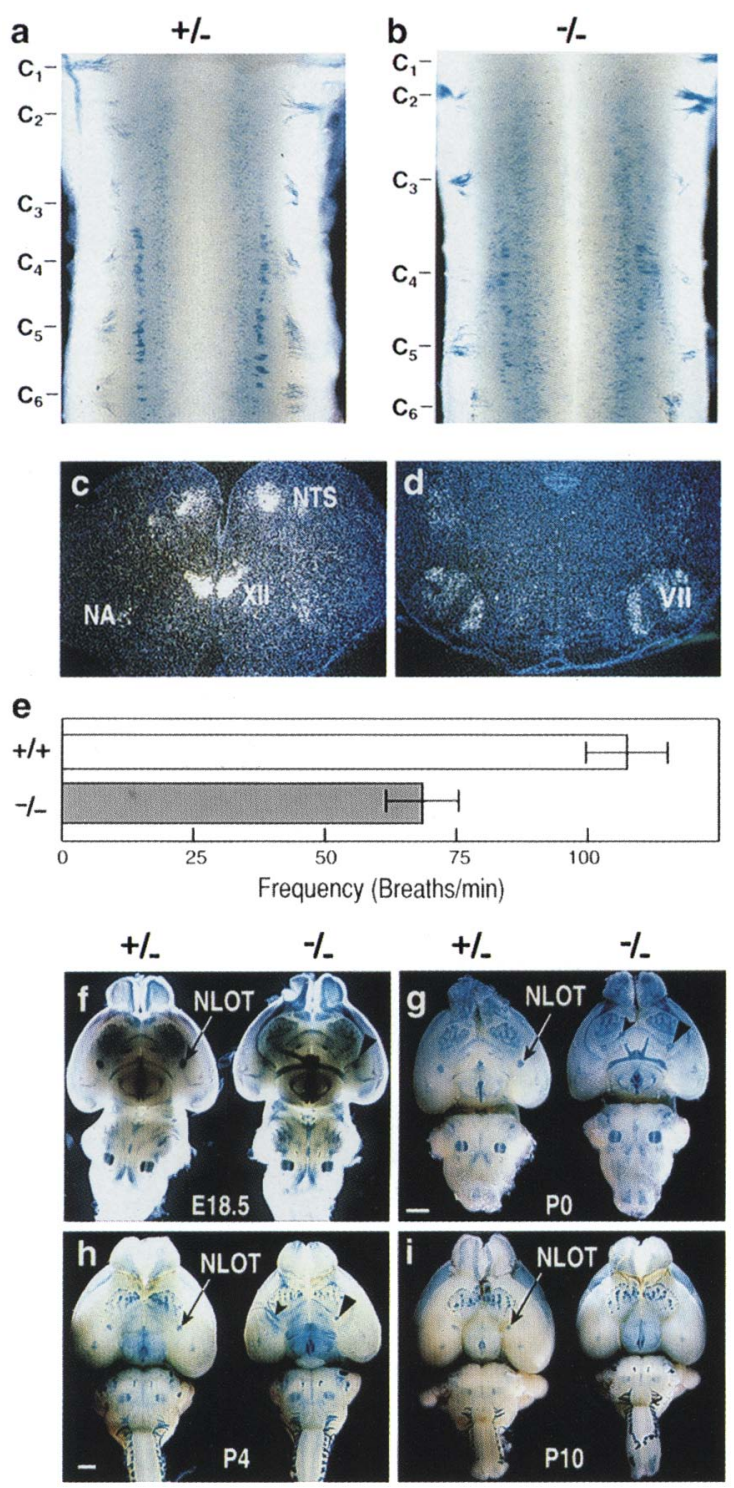

j

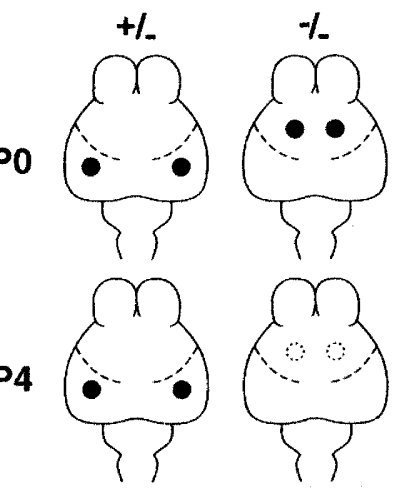

pressed under the control of the $P_{0}$ promotor in transgenic mice (Weinstein et al. 1995). Within the limitations of in situ hybridization, we observe normal levels of $\mathrm{P}_{0}, \mathrm{MBP}, \mathrm{MAG}$, and PMP22 gene expression in Tst-1/ Oct-6/SCIP-null mice, suggesting that if Tst-1/Oct-6/
Figure 6. Neuronal defects in Tst-1/Oct-6/SCIP mutant mice. (a) $\beta$-galactosidase stained cervical spinal cord of heterozygous newborn mouse. Cervical spinal nerves $\left(C_{1}-C_{6}\right)$ are visible because of the staining of Schwann cells, and the phrenic nuclei are located bilaterally between $\mathrm{C}_{3}$ and $\mathrm{C}_{6}$. $(b)$ Disorganization of phrenic nuclei from homozygous mutant newborn mouse is revealed by $\beta$-galactosidase staining. $\{c \mid$ In situ hybridization of a Tst-1/Oct-6/SCIP probe to a transverse section through a P0 $(+1+1$ brainstem, showing nucleus tractus solitarius (NTS), glossopharyngeal (XII) nucleus, and nucleus ambiguus (NA). (d) In situ hybridization of a Tst-1/Oct-6/SCIP probe to a transverse section through a $\mathrm{PO}(+1+)$ brainstem, showing facial (VII) nucleus. (e) Results of plethysmograph recordings of P0 $(+1+)$ and $(-1-1$ mice, showing reduced frequency of breathing in $(-1-)$ mice. Because the $(-1-)$ pups tended to gasp, and gasps were not distinguished from normal breaths in the analysis of respiratory rate, the actual respiratory rate may actually be lower in mutant pups than we have estimated. $(f)$ Heterozygous $(+\mid-)$ and homozygous mutant $(-1-)$ El8.5 brains stained for $\beta$-galactosidase, and cleared by infusion with $30 \%$ sucrose. NLOT refers to the nucleus of the lateral olfactory tract, which is replaced in the $(-/-)$ brain by novel $\beta$-galactosidase-expressing cells (large arrowhead) at a more internal position in the brain. $(g) \mathrm{PO}(+/-)$ and $(-/-)$ brains stained for $\beta$-galactosidase. Putative displaced NLOT cells (large arrowhead) can be observed in a more medial and anterior position in the $(-1-)$ brain. Additional abnormal $\beta$-galactosidase stainingcells are occasionally seen, and are marked with a small arrowhead. Scale bar, $1 \mathrm{~mm}$. (h) $\mathrm{P} 4(+/-)$ and $(-/-)$ brains. Novel $\beta$-galactosidase-stained cells and axon tracts in the $|-/-|$ brain are marked with large and small arrowheads, respectively. Scale bar, $1 \mathrm{~mm}$. (i) P10 $(+/-)$ and $(-/-)$ brains stained for $\beta$-galactosidase. NLOT cells are missing in the $|-|-\mid$ brain. Note also the disapperance of $\beta$-galactosidase staining in the facial (VII) nucleus in both $(+1-)$ and $(-1-)$ brainstems, suggesting that Tst-1/Oct-6/SCIP expression in these cells is transient. (j) Diagram depicting NLOT at P0 and P4. The broken lines represent the lateral cerebral sulcus, and the relative locations of normal and mutant NLOT cells $(0)$ have been exaggerated for clarity. The broken open circles in the $\mathrm{P} 4(-/-)$ brain represent mutant cells that are disappearing. Alternatively, the novel $\beta$-galactosidase-staining cells are unrelated to NLOT. In this case, NLOT neurons die before P0, or Tst-1/Oct-6/SCIP protein is required for its own expression in these cells.

SCIP does regulate these genes in vivo, its effect is small. Furthermore, Tst-1/Oct-6/SCIP mutant mice lack the hypertrophic "onion bulb" neuropathy associated with overexpression of PMP22 (for review, see Chance and Fischbeck 1994), suggesting that myelin structural genes 
Figure 7. Schematic diagram depicting arrest of $(-1-)$ Schwann cells at the ensheathment stage, whereas expression of major myelin genes is normal. Low-level expression of the genes depicted is not shown. Tst-1/Oct-6/SCIP expression is transient (Monuki et al. 1990; Scherer et al. 1994; S. Scherer, unpubl.) and precedes the peak of Krox-20 and myelin gene expression. Pax3 expression declines before myelination. (SC) Schwann cell; (A) axon.

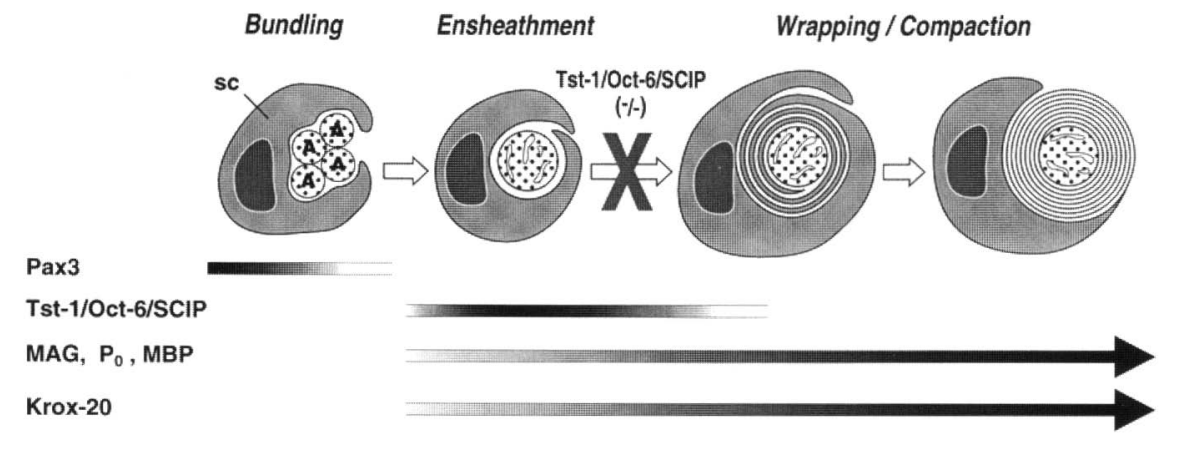

are not overexpressed in these mice. Because the $\mathrm{P}_{\mathrm{O}^{-}}$ $\triangle S C I P$ transgenic mice, unlike Tst-1/Oct-6/SCIP-null mice, are able to wrap axons, we postulate that under certain circumstances, $\triangle \mathrm{SCIP}$ is likely to act as a transcriptional activator in vivo, perhaps through interactions between its POU domain and other proteins. In muscle development, the DNA-binding domain of either the MADS-box factor myocyte-specific enhancer factor 2 (MEF2) or the helix-loop-helix (HLH) transcription factor myogenin is sufficient for a complex to form that activates target genes (Molkentin et al. 1995). The occasional myelinated axons in Tst-1/Oct-6/SCIP mutant mice, which may be analogous to the few myotubes that form in myogenin mutant mice (Hasty et al. 1993; Nabeshima et al. 1993), could be accounted for by the formation of a partial activating complex even in the absence of Tst-1/Oct-6/SCIP. Our results suggest that the function of Tst-1/Oct-6/SCIP in peripheral myelination is distinct from the regulation of the major myelin structural proteins. The genes that Tst-1/Oct-6/SCIP activate or repress are unknown; they could be involved in key aspects of axonal wrapping such as intracellular sig. naling or membrane biogenesis.

Other transcription factors also have key roles in the development of Schwann cells, and their expression patterns are also diagrammed in Figure 7. Pax 3 is expressed throughout development of the Schwann cell lineage, and in nonmyelinating Schwann cells; it appears to be required for the establishment and maintenance of embryonic Schwann cells, and its expression is down-regulated before myelination (Kioussi et al. 1995). Schwann cells from Krox-20 mutant mice also fail to wrap axons (Topilko et al. 1994), but these mutant Schwann cells differ from those that lack Tst-1/Oct-6/SCIP in two aspects. Occasional myelinating figures are not observed in Krox-20 mutant Schwann cells and they express reduced levels of $\mathrm{P}_{0}$ mRNA, in contrast to the apparently normal levels of $\mathrm{P}_{0}$ mRNA expression in comparably aged Tst1/Oct-6/SCIP mutant mice. Our results suggest that the absence of axonal wrapping in Krox-20 mutant mice could result from a failure of Tst-1/Oct-6/SCIP expression, whereas Krox-20 independently appears to regulate $\mathrm{P}_{0}$ mRNA expression. Alternatively, Tst-1/Oct-6/SCIP and Krox-20 are independently regulated, but they cooperate in the activation of axonal wrapping.

\section{Neuronal functions of the Tst-1/Oct-6/SCIP gene}

In contrast to its dramatic effects on Schwann cell differentiation, deletion of Tst-1/Oct-6/SCIP affects only a subset of the neurons that express it. Detailed examination of $\beta$-galactosidase marker gene expression reveals no differences between $(+1-)$ and $(-/-)$ mice in the vast majority of Tst-1/Oct-6/SCIP-expressing neurons. However, we did observe abnormalites in the position and/or number of phrenic motoneurons in mutant mice. Although this defect may cause the observed reduction in breathing frequency, other respiratory neurons, including those of the nucleus tractus solitarius and the nucleus ambiguus, may also require Tst-1/Oct-6/SCIP to obtain a normal differentiated phenotype. In concert with the phrenic motoneuron abnormalities, a failure of lung inflation was observed in neonatal Tst-1/Oct-6/ SCIP mutant mice. The Tst-1/Oct-6/SCIP $/-1-1$ mice therefore provide a useful model for further investigation into the neural control of pulmonary function.

A second neuronal defect in Tst-1/Oct-6/SCIP mutant mice involves the mismigration and disappearance of cells of the nucleus of the lateral olfactory tract. These neurons project to the olfactory bulb /de Olmos et al. 1978; Luskin and Price 1983) and the islands of Calleja in the olfactory tubercle (Luskin and Price 1983), and receive axonal projections from the olfactory bulb (Price 1973) and the amygdaloid basal nuclei (Savander et al. 1995); their mislocation in Tst-1/Oct-6/SCIP $(-/-)$ mice suggests that these mice may possess deficits in the processing of olfactory information. Many other olfactory neurons express Tst-1/Oct-6/SCIP (Alvarez-Bolado et al. 1995; data not shown/ but appear unaffected by its deletion. These findings are reminiscent of cell migration defects caused by mutations of the POU domain proteins Unc-86 (Finney and Ruvkin 1990), ceh-18 (Greenstein et al. 1994), and drifter (Anderson et al. 1995). Notably, nematodes that possess mutations in the Unc-86 gene are unable to chemotax (Finney and Ruvkin 1990).

\section{Related functions of Tst-1/Oct-6/SCIP and other POU domain proteins}

The functions of Tst-1/Oct-6/SCIP in development and differentiation are likely to overlap those of other POU- 
domain proteins, and this may account for some cell types that express Tst-1/Oct-6/SCIP, but appear to be unaffected by its deletion. Oligodendrocytes appear to myelinate normally in Tst-1/Oct-6/SCIP $(-/-)$ mice, perhaps because they also express other class III POU proteins (M. Wegner, unpubl.). In contrast, the only POU-domain proteins known to be expressed in Schwann cells are Tst-1/Oct-6/SCIP and Oct-1 (Kuhn et al. 1991). Multiple class III POU proteins are coexpressed with Tst-1/Oct-6/SCIP in neurons of cortical layers $2 / 3$ and 5 (Alvarez-Bolado et al. 1995), where no defect has been observed. In the medial habenula, Tst-1/Oct-6/ SCIP and the acetylcholine receptor subunit $\alpha 3$ are coexpressed, and Tst-1/Oct-6/SCIP has been reported to activate $\alpha 3$ in vitro (Yang et al. 1994). However, other POU-domain proteins are expressed in the medial habenula (Alvarez-Bolado et al. 1995), and $\alpha 3$ expression is unaffected in Tst-1/Oct-6/SCIP mutant mice (data not shown).

The target genes of Tst-1/Oct-6/SCIP in Schwann cells may be closely related to the genes that are regulated by POU-domain proteins in the differentiation of other cell types. Disruption of Oct- 2 arrests maturation of $\mathrm{B}$ cells without altering expression of several genes thought to be regulated by Oct-2 (Corcoran et al. 1993; Feldhaus et al. 1993). Therefore, the role of Tst-1/Oct$6 /$ SCIP in peripheral myelination may be conceptually similar to that of Oct-2 in the terminal differentiation of B cells, and may reflect the functions of other POU-domain proteins as well.

The results presented here establish a unique role for the Tst-1/Oct-6/SCIP gene product in the regulation of peripheral myelination, and in the differentiation of specific neurons. These data redefine the role of Tst-1/Oct6/SCIP in the differentiation of Schwann cells, and have implications for the etiology of demyelinating disorders. Some cases of arthrogryposis multiplex congenita with hypomyelinating neuropathy in humans appear to have Schwann cells that are arrested at the ensheathment stage (Charnas et al. 1988; Boylan et al. 1992), suggesting that the etiology of some of these cases could involve mutations of the Tst-1/Oct-6/SCIP gene.

\section{Materials and methods}

Construction of TKAB', a general vector for creating homologous recombinants by positive/negative selection in ES cells

To create a vector that could be used to generate a variety of knockout constructs that use positive/negative selection, a novel polylinker containing a number of unique rare and common restriction sites was fused to the 3 ' end of a PGK-tk expression cassette. Mouse sequences and the neo gene can be cloned into any of several common or rare sites, and the resulting knockout vector can then be linearized with one of several rare cutting restriction enzymes. To create this vector, $\mathrm{pBKSII}^{+}$ was cut with $A s p 718$ and $X h o I$, filled in, then ligated to the PGK-1-HSV1-tk insert from pGEM7(tk) (M.A. Rudnicki, Massachusetts Institute of Technology, Cambridgel that had been cut with EcoRI and SalI, then filled in. Most of the remaining polylinker of $\mathrm{pBKSII}^{+}$was subsequently replaced in two steps with oligonucleotides containing the new restriction sites. The resulting vector, $\mathrm{TKAB}^{\prime}$, is $5.9 \mathrm{~kb}$ in length, and consists of the PGK-tk expression cassette followed by SalI, ClaI, XbaI, EcoRI, HindIII, BamHI, XhoI, Sse8387, Nhe, Sfi-Pml, and NotI restriction sites.

\section{Construction of Tst-1/Oct-6/SCIP knockout vector}

Mouse Tst-1/Oct-6/SCIP genomic sequences were isolated from a Jl mouse ES cell genomic library in phage $\lambda$ (kindly provided by En Li, Whitehead Institute for Biomedical Research, Cambridge, MA). A 6.3-kb fragment of a $5^{\prime}$ Tst-1/Oct-6/SCIP sequence, flanked by the MscI site that cuts within the second codon of the mouse Oct- 6 sequence (Meijer et al. 1990; Suzuki et al. 1990), was ligated to the 5' BamHI site of the $\beta$-geo lacZneo fusion gene (P. Soriano and G. Friedrich, Baylor College of Medicine, Houston, TX) after the MscI site was modified by ligation of 8-mer BglII linkers (NE Biolabs). The first two amino acids of Tst-1/Oct- $6 /$ SCIP and $\beta$-geo are identical, and ligation of the BgIII and BamHI sites fused the codons for these amino acids to the third codon of $\beta$-geo. Subsequently, sequences 3 ' to the ClaI site in the LacZ portion of $\beta$-geo were replaced with unfused $L a C Z$ and $\mathrm{pMCl}-$ neo sequences that were obtained from the plasmid pIC19H- $\beta$-galpANeo B-B 1 (O. Chisaka and M. Capecchi, University of Utah, Salt Lake City). A 4.0-kb SacIIXhoI fragment that contains Tst-1/Oct-6/SCIP 3 ' coding and noncoding sequences was ligated to the $3^{\prime}$ end of the pMC1-neo gene. The resulting sequences were cloned into the vector TKAB'. A clone that contains Tst-1/Oct-6/SCIP 5 ' sequences adjacent to the $t k$ gene was used as the Tst-1/Oct-6/SCIP knockout vector, after being linearized with $\mathrm{XhoI}$.

\section{Production of mutant mice}

Mutant ES cells and mice were generated using standard techniques (Hogan et al. 1994), using Jl ES cells (kindly provided by En Li), which were grown in the presence of $1000 \mathrm{U} / \mathrm{ml}$ of leukemia inhibitory factor on mouse embryonic fibroblast feeder cells. Recombinant cell lines were selected using neomycin (GIBCO), and Gancyclovir (kindly provided by Syntex). Three independent heterozygous ES cell lines were detected by Southern analysis, using a $5^{\prime}$ probe that consists of $0.4 \mathrm{~kb}$ between the BgIII and NheI sites that are located $\sim 6 \mathrm{~kb} 5^{\prime}$ to the Tst-1 promoter, and a $3^{\prime}$ probe that consists of a $0.6-\mathrm{kb}$ XhoIBglII fragment located $4 \mathrm{~kb} 3^{\prime}$ to the Tst- 1 POU domain. Both probes are located outside of the knockout vector. Cells from all three lines were injected into C57BL/6J blastocysts. Chimeras derived from one line produced surviving agouti offspring when mated to C57BL/6 females, and were backcrossed either to C57BL/6J females, or to 129/Sv agouti females /kindly provided by Jeff Mann, Beckman Research Institute of City of Hope, Duarte, CA).

\section{Genotype analysis of mutant mice}

Initial litters from heterozygous intercrosses were analyzed by southern analysis of DNA extracted from the pups. Subsequently, the litters were analyzed by PCR, using the following primers: Neokopcr1, 5'-AGAGGCTATTCGGCTATGACTGGGCA-3'; Neokopcr2, 5'-CCACACCCAGCCGGCCACAGTCGATGA-3'; Tstkopcr3， 5'-CACTGCACGAGGACGGCCAC-3'; and Tstkopcr4, 5'-TCGAGCGCGCCTTTGACACC-3'. Ten-milliliter reactions that were $10 \mu \mathrm{M}$ Tris $(\mathrm{pH} 8.3)$, $50 \mathrm{mM} \mathrm{KCl}, 1.5 \mathrm{mM} \mathrm{MgCl}_{2}, 200 \mu \mathrm{M}$ each dNTP, $10 \%$ DMSO, contained $0.1 \mu \mathrm{g}$ of each of the four primers, $0.2 \mu \mathrm{l}$ of Taq polymerase, and $0.5 \mu \mathrm{l}$ DNA template were cycled in a PerkinElmer 9600 PCR machine at $94^{\circ} \mathrm{C}, 30 \mathrm{sec} ; 65^{\circ} \mathrm{C}, 30 \mathrm{sec}_{;} 72^{\circ} \mathrm{C}, 30$ 
sec; for 40 cycles, followed by $5 \min , 72^{\circ} \mathrm{C} .+/+,+/-,-/-$, and no DNA controls were used with each set of reactions. Reaction products of $593 \mathrm{bp}$ for the neo primers and $497 \mathrm{bp}$ for the Tst-1 primers were visualized by ethidium bromide staining after electrophoresis on $1.2 \%$ TBE-agarose gels.

\section{Microscopy of myelin figures}

Mice were perfused with $3.2 \%$ glutaraldehyde and $3 \%$ paraformaldehyde in $0.1 \mathrm{M}$ phosphate buffer $(\mathrm{pH} 7.2)$, after which the spinal cords and sciatic nerves were removed and placed in fresh fixative overnight at $4^{\circ} \mathrm{C}$. The tissues were osmicated, dehydrated, infiltrated, and embedded in epoxy resin. Semithin sections were stained with methylene blue-azure II-basic fuschin. For electron microscopy, tissues were prepared as described above. Thin sections were stained with lead citrate and uranyl aceate, before electron microscopy.

\section{Immunohistochemistry}

Tst-1/Oct-6/SCIP immunoreactivity was revealed with diaminobenzidine using an $\mathrm{ABC}$ kit (Vector) in tissues that typically were fixed in $4 \%$ paraformaldehyde, frozen, sectioned, and incubated with a $1: 1000$ dilution of a rabbit polyclonal antiserum raised against a full-length Tst- $1 /$ Oct- $6 /$ SCIP protein that had been expressed from baculovirus, and kindly provided by $M$. Wegner (Zentrum für Moleculare Neurobiologie, Hamburg, Germany) and S. Rhodes (IUPUI, Indianapolis).

Sciatic nerves were fixed in $4 \%$ paraformaldehyde, infiltrated with $20 \%$ sucrose, and embedded in OCT. Transverse sections were mounted on glass slides, blocked in $5 \%$ fish skin gelatin, incubated overnight in primary antibody at $4^{\circ} \mathrm{C}$, then visualized with fluorescein-conjugated donkey anti-rabbit antiserum (Jackson ImmunoResearch) using a Leica scanning laser confocal microscope. The following rabbit antisera (and dilutions) were used: anti-laminin $(1: 500)$, anti- $P_{0} \quad(1: 250)$, anti-MAG (1:250), and anti-periaxin $(1: 500)$, which were obtained from Sigma, Dr. D. Colman (Mt. Sinai School of Medicine, New York, NY), Dr. J. Salzer (New York University School of Medicine, New York), and Dr. P. Brophy (University of Edinburgh, Scotland\}, respectively.

$\beta$-galatosidase staining was performed as described (Hogan et al. 1994).

\section{In situ hybridization}

Tissues were fixed in formalin, frozen in a 1:1 mixture of OCT and aquamount, sectioned at $20 \mu \mathrm{m}$, and hybridized as described (Simmons et al. 1989). The following antisense probes were used: MAG, a 900-bp EcoRI fragment of rat-coding region; $\mathrm{P}_{0}$; 1.7-kb rat cDNA; MBP, 660-bp of rat-coding sequence. $\mathrm{p} 75$ NGFR, 350 bp of mouse exon 3; and Tst-1/Oct-6/SCIP, $0.7 \mathrm{~kb}$ of sequence between the AlwN1 and Pst-1 sites (Meijer et al. 1990; Suzuki et al. 1990).

\section{Breathing analysis}

Respiration of mouse pups was measured using a plethysomograph that consisted of a pneumotachograph (A. Fleisch Co.) attached to a chamber in which the mouse pup breathed. A mixture of $\mathrm{O}_{2}, \mathrm{CO}_{2}$ and $\mathrm{N}_{2}$ flowed around the pup's nose and mouth, which protruded from the chamber through a hole in a piece of latex rubber. The gas mixture was adjusted using a rotameter, and its composition was monitored by continuous sampling using a mass spectrometer. Data were collected on a chart recorder, and on an IBM PC, using Labdat 7.0 software.

\section{Acknowledgments}

We thank Bob McEvilly for Tst-1 probes, Bob McEvilly and Dan Drolet for their contributions toward generating recombinant ES cell lines, and Mary Ayers, Farideh Hooshmand, and Adam Uribe for assistance in maintaining mice, and Leslie Hempleman and David Shuffleton for assistance in breathing analysis. We thank Michael Wegner and Simon Rhodes for the anti-Tst-1 antibody, and Aimee Ryan for assistance with anti-Tst-1 immunohistochemistry. We gratefully acknowledge En Li for the J1 ES cells and genomic library; Glen Friedrich for the $\beta$-geo construct; Anne Boulet and Mario Capecchi for the LacZ-pMC1neo cassette; Jeff Mann for the 129/Sv mice; Greg Lemke, John Kamholz, and Jim Salzer for the $P_{0}, M B P$, and MAG in situ probes, respectively. We thank Bogi Anderson, Aimee Ryan, and Linda Erkman for critically reviewing the manuscript; Paul Sawchenko for neuroanatomical advice, and Peggy Myer for her expertise in preparing the figures. These studies were conducted under grants from the National Institutes of Health (NIH) to M.G.R. and S.S.S., and postdoctoral fellowships from the NIH and U.S. Army Breast Cancer Initiative to J.R.B. Ir. M.G.R. is an Investigator of the Howard Hughes Medical Institute.

The publication costs of this article were defrayed in part by payment of page charges. This article must therefore be hereby marked "advertisement" in accordance with 18 USC section 1734 solely to indicate this fact.

\section{References}

Adlkofer, K., R. Martini, A. Aguzzi, J. Zielasek, K.V. Toyka, and U. Suter. 1995. Hypermyelination and demyelinating peripheral neuropathy in Pmp22-deficient mice. Nature Genet. 11: $274-280$.

Alvarez-Bolado, G., M.G. Rosenfeld, and L.W. Swanson. 1995. Model of forebrain regionalization based on spatiotemporal patterns of POU-III homeobox gene expression, birthdates, and morphological features. /. Comp. Neurol. 355: 237-295.

Anderson, M.G., G.L. Perkins, P. Chittick, R.J. Shrigley, and W.A. Johnson. 1995. drifter, a Drosophila POU-domain transcription factor, is required for correct differentiation and migration of tracheal cells and midline glia. Genes \& Dev. 9: $123-137$.

Avraham, K.B., B.C. Cho, D. Gilbert, H. Fujii, K. Okamoto., T. Shimazaki, T. Ito, H. Shoii, Y. Wakamatsu, H. Kondoh, N. Takahashi, M. Muramatsu, H. Hamada, N.G. Copeland, and N.A. Jenkins. 1993. Murine chromosomal location of four class III POU transcription factors. Genomics 18: 131-133.

Bodner, M., J-L. Castrillo, L.E. Theill, T. Deerinck, M. Ellisman, and M. Karin. 1988. The pituitary-specific transcription factor GHF-1 is a homeobox-containing protein. Cell 55: 505518.

Boylan, D.M Ferriero, C.M. Greco, R.A. Sheldon, and M. Dew. 1992. Congenital hypomelination neuropathy with arthrogryposis multiplex congenita. Ann. Neurol. 31: 337-340.

Brunden, K.R. and J.F. Poduslo. 1987. Lysosomal delivery of the major myelin glycoprotein in the absence of myelin assembly: Posttranslational regulation of the level of expression by Schwann cells. J. Cell Biol. 104: 661-669.

Bunge, M.B. 1993. Schwann cell regulation of extracellular matrix biosythesis and assembly. In Peripheral neuropathy, 3rd ed. (ed. P.J. Dyck, P.K. Thomas, J.W. Griffin, P.A. Low, and J.F. Poduslol, pp. 299-316 W.B. Saunders, Philadelphia, PA.

Chance, P.F. and K.H. Fischbeck. 1994. Molecular genetics of Charcot-Marie-Tooth disease and related neuropathies. Hum. Mol. Genet. 3: 1503-1507.

Charnas, L., B. Trapp, and J. Griffin. 1988. Congenital absence of 
peripheral myelin: Abnormal Schwann cell development causes lethal arthrogyposis multiplex congenita. Neurology 38: 966-974.

Clerc, R.G., L.M. Corcoran, J.H. LeBowitz, D. Baltimore, and P.A. Sharp. 1988. The B-cell-specific Oct-2 protein contains POU box- and homeo box-type domains. Genes \& Dev. 2: $1570-1581$.

Collarini, E.J., N. Pringle, H. Mudhar, G. Stevens, R. Kuhn, E.S. Monuki, G. Lemke, and W.D. Richardson. 1991. Growth factors and transcription factors in oligodendrocyte development. J. Cell Sci. 15: 117-123.

Collarini, E.J., R. Kuhn, C.J. Marshall, E.S. Monuki, G. Lemke, and W.D. Richardson. 1992. Down-regulation of the POU transcription factor SCIP is an early event in oligodendrocyte differentiation in vitro. Development 116: 193-200.

Corcoran, L.M., M. Karvelas, G.J.V. Nossal, Z-S. Ye, T. Jacks, and D. Baltimore. 1993. Oct-2, although not required for early B-cell development, is critical for later B-cell maturation and for postnatal survival. Genes \& Dev. 7: 570-582.

de Olmos, J., H. Hardy, and L. Heimer. 1978. The afferent connections of the main and the accessory olfactory bulb formations in the rat: An experimental HRP-study. J. Comp. Neurol. 181: 213-244.

Dong, Z., A. Brennan, N. Liu, Y. Yarden, G. Lefkowitz, R. Mirsky, and K.R. Jessen. 1995. Neu differentiation factor is a neuron-glia signal and regulates survival, proliferation, and maturation of rat Schwann cell precursors. Neuron 15: 585569.

Duffin, J., K. Ezure, and J. Lipski. 1995. Breathing rhythm generation: Focus on the rostral ventilatory medulla. News Physiol. Sci. 10: 133-140.

Eccleston, P.A. 1992. Regulation of Schwann cell proliferation: Mechanisms involved in peripheral nerve development. Exp. Cell Res. 199: 1-9.

Faus, I., H-J. Hsu., and E. Fuchs. 1994. Oct-6: A regulator of keratinocyte gene expression in stratified squamous epithelia. Mol. Cell. Biol. 14: 3263-3275.

Feldhaus, A.L., C.A. Klug, K.L. Arvin, and H. Singh. 1993. Targeted disruption of the Oct-2 locus in a B cell provides genetic evidence for two distinct cell type-specific pathways of octamer element-mediated gene activation. EMBO $J$. 12: $2763-2772$.

Feldman, J.L. and J.C. Smith. 1995. In Regulation of breathing (ed. J.A. Demsey and A.I. Pack). Marcel Dekker, Inc. New York, NY.

Finney, M. and G. Ruvkun. 1990. The unc-86 gene product couples cell lineage and cell identity in C. elegans. Cell 63: 895905.

Finney, M., G. Ruvkun, and H.R. Horvitz. 1988. The C. elegans cell lineage and differentiation gene unc-86 encodes a protein with a homeodomain and extended similarity to transcription factors. Cell 55: 757-769.

Frantz, G.D., A.P. Bohner, R.M. Akers, and S.K. McConnell. 1994. Regulation of the POU domain gene SCIP during cerebral cortical development. J. Neurosci. 14: 472-485.

Gavrilovic, J., A. Brennan, R. Mirsky, and K.R. Jessen. 1995. Fibroblast growth factors and insulin growth factors combine to promote survival of rat Schwann cell precursorswithout induction of DNA synthesis. Eur. J. Neurosci. 7: 77-85.

Giese, K.P., R. Martini, G. Lemke, P. Soriano, and M. Schachner. 1992. Mouse $\mathrm{P}_{0}$ gene disruption leads to hypomyelination, abnormal expression of recognition molecules, and degeneration of myelin and axons. Cell 71: 565-576.

Gillespie, C.S., D.L. Sherman, G.E. Blair, and P.J. Brophy. 1994. Periaxin, a novel protein of myelinating Schwann cells with a possible role in axonal ensheathment. Neuron 12: 4975082.

Greenstein, D, S. Hird, R.H.A. Plasterk, Y. Andachi, Y. Kohara, B. Wand, M. Finney, and G. Ruvkun. 1994. Targeted mutations in the Caenorhabditis elegans POU homeo box gene ceh-18 cause defects in oocyte cell cycle arrest, gonad migration, and epidermal differentiation. Genes \& Dev. 8: 1935-1948.

Hasty, P., A. Bradley, J.H. Morris, D.G. Edmonson, J.M. Venuti, E.N. Olson, and W.H. Klein. 1993. Muscle deficiency and neonatal death in mice with a targeted mutation in the myogenin gene. Nature 364: 501-506.

He, X., M.N. Treacy, D.M. Simmons, H.A. Ingraham, L.W. Swanson, and M.G. Rosenfeld. 1989. Expression of a large family of POU-domain regulatory genes in mammalian brain development. Nature 340: 35-42.

He, X., R. Gerrero, D.M. Simmons, R.E. Park, C.R. Lin, L.W. Swanson, and M.G. Rosenfeld. 1991. Tst-1, a member of the POU domain gene family, binds the promoter of the gene encoding the cell surface adhesion molecule $\mathrm{P}_{0}$. Mol. Cell. Biol. 11: 1739-1744.

Herr, W. and M.A. Cleary. 1995. The POU domain: Versatility in transcriptional regulation by a flexible two-in-one DNA binding domain. Genes \& Dev. 9: 1679-1693.

Herr, W., R.A. Sturm, R.G. Clerc, L.M. Corcoran, D. Baltimore, P.A. Sharp, H.A. Ingraham, M.G. Rosenfeld, M. Finney, G. Ruvkun, and H.R. Horvitz. 1988. The POU domain: A large conserved region in the mammalian pit-1, oct-1, oct-2, and Caenorhabditis elegans unc-86 gene products. Genes \& Dev. 2: 1513-1516.

Hildebrand, C., C.M. Bowe, and I.L. Remahl. 1994. Myelination and myelin sheath remodelling in normal and pathological PNS nerve fibers. Prog. Neurobiol. 43: 85-141.

Hogan, B., R. Beddington, F. Constantini, and E. Lacy. 1994. Manipulating the mouse embryo: A laboratory manual, 2nd ed. Cold Spring Harbor Press, Cold Spring Harbor, NY.

Ingraham, H.A., R. Chen, H.J. Mangalam, H.P. Elsholtz, S.E. Flynn, C.R. Lin, D.M. Simmons, L. Swanson, and M.G. Rosenfeld. 1988. A tissue-specific transcription factor containing a homeodomain specifies a pituitary phenotype. Cell 55: 519-529.

Jessen, K.R. and R. Mirsky. 1991. Schwann cells precursors and their development. Glia 4: 185-194.

- 1992. Schwann cells: Early lineage, regulation of proliferation and control of myelin formation. Curr. Opin. Neurobiol. 2: $575-581$.

Jessen, K.R., A. Brennan, L. Morgan, R. Mirsky, A. Kent, Y. Hashimoto, and J. Gavrilovic. 1994. The Schwann cell precursor and its fate: A study of cell death and differentiation during gliogenesis in rat embryonic nerves. Neuron 12: 509527.

Kioussi, C., M.K. Gross, and P. Gruss. 1995. Pax3: A paired domain gene as a regulator in PNS myelination. Neuron 15: 553-562.

Ko, H-S., P. Fast, W. McBride, and L.M. Staudt. 1988. A human protein specific for the immunoglobulin octamer DNA motif contain a functional homeobox domain. Cell 855: 135144.

Kuhn, R., E.S. Monuki, and G. Lemke. 1991. The gene encoding the transcription factor SCIP has features of an expressed retroposon. Mol. Cell. Biol. 11: 4642-4650.

Leger, H., E. Sock, K. Renner, F. Grummt, and M. Wegner. 1995. Functional interaction between the POU domain protein Tst-1/Oct- 6 and the high-mobility-group protein HMG-I/Y. Mol. Cell. Biol. 15: 3738-3747.

Luskin, M.B. and J.L. Price. 1983. The topographic organization 
of associational fibers of the olfactory system in the rat, including centrifugal fibers to the olfactory bulb. I. Comp. Neurol. 216: 264-291.

Martini, R., M.H. Mohajeri, S. Kasper, K.P. Giese, and M. Schachner. 1995. Mice doubly deficient in the genes for $P_{0}$ and myelin basic protein show that both proteins contribute to the formation of the major dense line in peripheral nerve myelin. J. Neurosci. 15: 4488-4495.

Meijer, D., A. Graus, R. Kraay, A. Langeveld, M.P. Mulder, and G. Grosveld. 1990. The octamer binding factor Oct-6: cDNA cloning and expression in early embryonic cells. Nucleic Acids Res. 9: 2241-2247.

Meijer, D., A. Graus, and G. Grosveld. 1992. Mapping the transactivating domain of the Oct-6 POU transcription factor. Nucleic Acids Res. 9: 2241-2247.

Mezei, C. 1993. Myelination in the peripheral nerve during development. In Peripheral Neuropathy, 3rd ed. (ed. P.J. Dyck, P.K. Thomas, J.W. Griffin, P.A. Low, and J.F. Poduslol pp. 267-281. W.B. Saunders, Philadelphia, PA.

Molkentin, J.D., B.L. Black, J.F. Martin, and E.N. Olson. 1995. Cooperative activation of muscle gene expression by MEF2 and myogenic HLH proteins. Cell 83: 1125-1136.

Montag, D., K.P. Giese, U. Bartsch, R. Martini, Y. Lang, H. Bluthmann, J. Karthigasan, D.A. Kirschner, E.S. Wintergerst, K.-A. Nave, J. Zielasek, K.V. Toyka, H.-P. Lipp, and M. Schachner. 1994. Mice deficient for the myelin-associated glycoprotein show subtle abnormalities in myelin. Neuron 13: $229-246$.

Monuki, E.S., G. Weinmaster, R. Kuhn, and G. Lemke. 1989. SCIP: A glial POU domain gene regulated by cyclic AMP. Neuron 3: 783-793.

Monuki, E.S., R. Kuhn, G. Weinmaster, B.D. Trapp, and G. Lemke. 1990. Expression and activity of the POU transcription factor SCIP. Science 249: 1300-1303.

Monuki, E.S., R. Kuhn, and G. Lemke. 1993a. Repression of the myelin $\mathrm{P}_{\mathrm{O}}$ gene by the POU transcription factor SCIP. Mech. Dev. 42: 15-32.

- 1993b. Cell-specific action and mutable structure of a transcription factor effector domain. Proc. Natl. Acad. Sci. 90: $9978-9982$.

Morgan, L., K.R. Jessen, and R. Mirsky. 1991. The effects of cAMP on differentiation of cultured Schwann cells: Progression forom an early phenotype $\left(04^{+}\right)$to a myelin phenotype $\left\langle\mathrm{P}_{0}{ }^{+}, \mathrm{GFAP}^{-}, \mathrm{N}-\mathrm{CAM}{ }^{-}\right.$, NGF-receptor $\left.{ }^{-}\right\}$depends on growth inhibition. I. Cell Biol. 112: 457-467.

Müller, M.M., S. Ruppert, W. Schaffner, and P. Matthias. 1988. A cloned octamer trascription factor stimulates transcription from lymphoid-specific promotors in non-B cells. $\mathrm{Na}$ ture 336: 544-551.

Nabeshima, Y., K. Hanaoka, M. Hayasaka, E. Esumi, S. Li, I. Nonaka, and Y. Nabeshima. 1993. Myogenin gene disruption results in perinatal lethality because of severe muscle defect. Nature 364: 532-535.

Price, J.L. 1973. An autoradiographic study of complemetary laminar patterns of termination of afferent fibers to the olfactory cortex. I. Comp. Neurol. 150: 87-108.

Renner, K., H. Leger, and M. Wegner. 1994. The POU domain protein Tst-1 and papovaviral late tumor antigen function synergistically to stimulate glia-specific gene expression of JC virus. Proc. Nat. Acad. Sci. 91: 6433-6437.

Rohdewohld, H. and P. Gruss. 1992. The gene for the POU domain transcription factor Oct- 6 maps to the distal end of mouse chromosome 4. Mamm. Genome 3: 119-121.

Savander, V., C.-G. Go, J.E. LeDoux, and A. Pitkänen. 1995. Intrinsic connections of the rat amygdaloid complex: Projections originating in the basal nucleus. I. Comp. Neurol.
361: 345-368.

Scheidereit, C., J.A. Cromlish, T. Gerster, K. Kawakami, C.-G. Balmaceda, R.A. Currie, and R.G. Roeder. 1988. A human lymphoid-specific transcription factor that activates immunoglobulin genes is a homoeobox protein. Nature 336: 551557.

Scherer, S.S., D. Wang, R. Kuhn, G. Lemke, L. Wrabetz, and J. Kamholz. 1994. Axons regulate Schwann cell expression of the POU transcription factor SCIP. I. Neurosci. 14: 19301942.

Simmons, D., J.L. Arriza, and L.W. Swanson. 1989. Complete protocol for in situ hybridization in brain and other tissues with radiolabeled single-stranded RNA probes. J. Histotechnol. 12: 169-181.

Snipes, G.J. and U. Suter. 1995. Molecular anatomy and genetics of myelin proteins in the peripheral nervous system. I. Anat. 186: $483-494$.

Stirling, C.A. 1975. Abnormalities in Schwann cell sheaths in spinal nerve roots of dystrophic mice. I. Anat. 119: 169-180.

Sturm, R.A., G. Das, and W. Herr. 1988. The ubiquitous octamer-binding protein Oct- 1 contains a POU domain with a homeo box subdomain. Genes \& Dev. 2: 1582-1599.

Suzuki, N., H. Rohdewohld, T. Neuman, P. Gruss, and H.R. Schöler. 1990. Oct-6: A POU transciption factor expressed in embryonal stem cells and in the developing brain. EMBO $\mathrm{F}$. 9: 3723-3732.

Topilko, P., S. Schneider-Maunoury, G. Levi, A. Baron-Van Evercooren, A.B.Y. Chennoufi, T. Seitanidou, C. Babinet, and P. Charnay. 1994. Krox-20 controls myelination in the peripheral nervous system. Nature 371: 796-799.

Verrijzer, C.P. and P.C. Van der Vliet. 1993. POU domain transcription factors. Biochem. Biophys. Acta 1173: 1-21.

Webster, H. deForest. 1993. Development of peripheral nerve fibers. In Peripheral neuropathy 3rd ed. (ed. P.J. Dyck, P.K. Thomas, J.W. Griffin, P.A. Low, and J.F. Poduslol, pp. 243266. W.B. Saunders, Philadelphia, PA.

Wegner, M., D.W. Drolet, and M.G. Rosenfeld. 1993a. POUdomain proteins: Structure and function of developmental regulators. Curr. Opin. Cell Biol. 5: 488-498.

- 1993b. Regulation of JC virus by the POU-domain trancription factor Tst-1: Implications for progressive multifocal leukoencephalopathy. Proc. Natl. Acad. Sci. 90: 4743-4747.

Weinberg, H.J., P.S. Spencer, and C.S. Raine. 1975. Aberrant PNS development in dystrophic mice. Brain Res. 88: 532537.

Weinstein, D.E., P.G. Burrola, and G. Lemke. 1995. Premature Schwann cell differentiation and hypermyelination in mice expressing a targeted antagonist of the POU trancription factor SCIP. Mol. Cell. Neurosci. 6: 212-229.

Xu, H., X.-R. Wu, U.M. Wewer, and E. Engvall. 1994. Murine muscular dystrophy caused by a mutation in the laminin a2 (Lama2) gene. Nature Genet. 8: 297-301.

Yang, X., J. McDonough, D. Fyodorov, M. Morris, F. Wang, and E.S. Deneris. 1994. Characterization of an acetylcholine receptor $\alpha 3$ gene promoter and its activation by the POU domain factor SCIP/Tst-1. I. Biol. Chem. 269: 10252-10264.

Zwart, R., L. Broos, G. Grosveld, and D. Meijer. 1996. The restricted expresssion pattern of the POU factor Oct- 6 during early development of the mouse nervous system. Mech. Dev. 54: 185-194. 


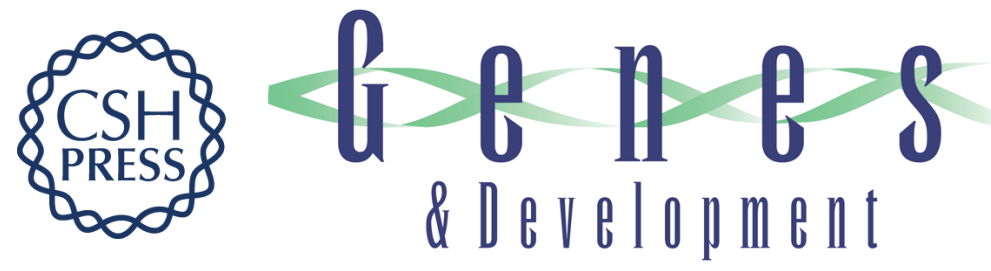

\section{Tst-1/Oct-6/SCIP regulates a unique step in peripheral myelination and is required for normal respiration.}

J R Bermingham, S S Scherer, S O'Connell, et al.

Genes Dev. 1996, 10:

Access the most recent version at doi:10.1101/gad.10.14.1751

References This article cites 73 articles, 23 of which can be accessed free at:

http://genesdev.cshlp.org/content/10/14/1751.full.html\#ref-list-1

License

Email Alerting

Service

Receive free email alerts when new articles cite this article - sign up in the box at the top right corner of the article or click here.

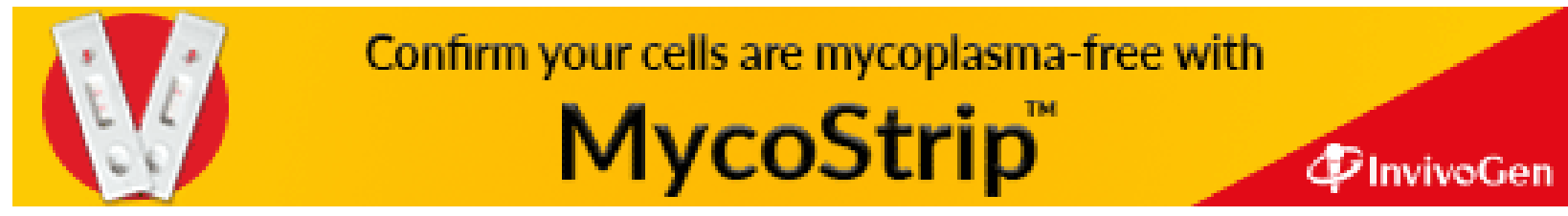

